and was a member of the Executive Committee. He was elected a member of the National Academy of Sciences, a Foreign Correspondent of the Geological Society of London, and a Fellow of the Geological Society of America. In 1900 he was elected President of the Connecticut Academy of Arts and Sciences, and filled the office for two years.

"In 1899 he presented his entire collection of fossils, containing upwards of 100,000 specimens, to Yale Museum. The gift was without conditions, and was given 'in grateful recognition of the honours and favours conferred upon me during my connection with the University.'

"Although Professor Beecher was interested in stratigraphic and descriptive palæontology, he published almost nothing in either branch of the science. Of stratigraphic and faunal papers he has five. Of new species apparently not more than thirty-one were described by him. Besides these he proposed seven new genera and seven new orders.

"His most philosophic paper, and the one which he himself thought best, is entitled "The Origin and Significance of Spines. A study in evolution.' He states here that all spinose species when young are devoid of spines, and are derived from non-spinose ancestors. Forms attaining the limit of spine differentiation leave no descendants, and out of spinose types no new types are developed.

"Charles E. Beecher's scientific writings amount to about sixty-five in number. His standing among biologists and palæontologists was high, and he was the leader among the students of Brachiopoda and Trilobita. His palæontological work at Yale was essentially of a biological and philosophical character. As a preparator of fossils be had no equal, and as a collector was one of the best. He had the artistic temperament, and made most of the illustrations for his publications. He was a slow and very careful worker. Those who knew him well saw in him an enthusiast, but his exuberance was al ways held in check by his judicial qualities, which character made him also an excellent counsellor. He travelled extensively, read wisely, was a lover of the English masters and of Herbert Spencer's philosophy. He was orderly in his work, and, as he had the 'museum instinct' well developed, he made one of the best of museum curators."-Professor Charles Schuchert.

His past students bear the highest testimony to his worth as a teacher in science, both as a lecturer and as a demonstrator in the laboratory. As a friend, all who knew him appreciated his many excellent qualities and his sterling worth.

[Kindly favoured by Miss Lucy P. Bush from the Yale Alumni Weekly, New Haven, Conn., March 2nd, 1904.]

\title{
SIR CLEMENT LE NEVE FOSTER, D.Sc., F.R.S.
} Bony March 23, 1841. Died April 19, 1904.

In the death of Sir Clement Foster we mourn the loss of a geologist the most distinguished in this country for his scientific and practical knowledge of metalliferous mining, and of all matters relating to stone quarries and slate-mines. 
The second son of Peter Le Neve Foster (for many years Secretary of the Society of Arts), he was born at Camberwell, and received his early education at Boulogne and Amiens. He then studied successively at the Royal School of Mines and at the Mining College of Freiberg, in Saxony, and eventually took the degree of Doctor of Science at the University of London.

In 1860 he was appointed an Assistant Geologist on the Geological Survey, working for a few years in the Wealden area and among the Carboniferous rocks of Derbyshire. Conjointly with his colleague William Topley, the now classic paper "On the Superficial Deposits of the Valley of the Medway, with remarks on the Denudation of the Weald," was read before the Geological Society in 1865. The authors sought to prove that old gravel of the Medway occurs 300 feet above the present level of the river, and that, granting this to be the case, there was no difficulty in admitting that the present features of the Wealden area were sculptured by rain and rivers. Later on Foster was part author of the Memoir on the Geology of North Derbyshire (Geol. Survey, 1869). He retired from the Geological Survey in 1865, not without much personal regret at leaving the congenial and active field-work of that institution; he retired simply because the prospects of earning a reasonable income were too remote. He now devoted his attention especially to mineralogy and mining-lecturing on these subjects in Cornwall, and examining several important mineral districts in different parts of the world. He brought before the Geological Society notes on Celestine in Egypt (with H. Bauerman), and an account of the Caratal goldfield in Venezuela. In 1872 he was appointed an Inspector of Mines under the Home Office, and served for about eight years in the south-west of England. The results of his observations on mines in Cornwall and Devon were brought before the Geological Society and before local Societies in Cornwall. In 1880 he was given charge of the North Wales district, and resided at Llandudno until his retirement from the Home Office in 1901. Meanwhile, on the death of Sir Warington Smyth, Foster was appointed in 1890 to the professorship of mining at the Royal College of Science, a post which he held until the time of his death. The work of his later years is largely embodied in the Reports on Mines and Quarries issued annually by the Home Office. He was author also of an important treatise on "Ore and Stone Mining," of which five editions have been issued, and only last year he published an excellent handbook on "The Elements of Mining aud Quarrying."

His wide knowledge and the charm of his personal character made him known and beloved by a large circle of friends, while his services on committees and as a juror were in frequent request. His last important function was as a member of the present Royal Commission on Coal supplies. He was elected a Fellow of the Royal Society in 1893, and last year the honour of knighthood was conferred upon him. 